\title{
SVEIKATOS PRIEŽIŪROS IR SOCIALINIO DARBO STUDIJŲ PROGRAMŲ STUDENTŲ PROFESIJOS PASIRINKIMO YPATUMAI
}

\author{
Ramutė Rimkienė, Danguolė Grūnovienė, Albina Vaičiulevičienė \\ Kauno kolegija, Kaunas, Lietuva
}

Ramutẻ Rimkienẻ. Socialinių mokslų magistrẻ. Kauno kolegijos Sveikatos priežiūros fakulteto lektorẻ. Mokslinių tyrimų kryptis — praktinio mokymo(-si) kokybè, profesinè identifikacija.

\begin{abstract}
SANTRAUKA
Profesijos pasirinkimas vienas iš labai svarbiu žingsniu žmogaus gyvenime. Nuo tinkamo profesijos pasirinkimo priklauso asmens psichologinè, socialinè, ekonominè büsena, dirbdamas mègstamq darbq žmogus jaučiasi svarbus, siekia tobulinti savo žinias ir igūdž̃us, dirba jausdamas pasitenkinima. Profesijos rinkimasis sudètingas, daugiaprasmis, nesibaigiantis, trunkantis visa gyvenima procesas, kuri veikia ìvairūs vidiniai ir išsoriniai veiksniai. Straipsnyje nagrinejjama sveikatos priežiūros ir socialinio darbo studiju programu studentu profesijos pasirinkimo ypatumai, veiksniu reikšmingumas pasirenkant studijas, bandoma išsiaiškinti, kokie veiksniai svarbesni kryptingai ir nekryptingai studiju programas pasirinkusiems studentams.
\end{abstract}

Tyrimo tikslas — atskleisti sveikatos priežiüros ir socialinio darbo studiju programu studentu profesijos pasirinkimo ypatumus.

Mokslininku nuomone, profesijos pasirinkima lemia vidiniai ir išoriniai veiksniai. Vidiniams veiksniams priskirtini asmens polinkiai, interesai, gabumai, savęs pažinimas, asmeninès savybès, vertybès, nuostatos ir kt., išoriniams bendrasis pasirengimas, žinios apie pasirinkta profesija, žiniu, igüdžiu ir mokejjimu lygmuo, darbo rinkos tendencijos, šeimos ir artimuju itaka profesijos pasirinkimui ir kiti veiksniai, svarbūs asmenybès profesiniam apsisprendimui.

Tyrimo rezultatai atskleidè, kad vidiniai studiju pasirinkimo veiksniai yra stipresni už išorinius, bet abi veiksniu grupès glaudžiai susijusios ir stipriai veikia viena kita. Koreliacine analizé parodè, kad didejjant vienai veiksniu grupei didèja ir kita. Spirmeno koreliacijos koeficientas $\left(R_{s}=0,381 ; p=0,00\right)$ rodo statistiškai patikima, silpna teigiama ryši tarp kintamuju. Du trečdaliai respondentu studijas rinkosi kryptingai — pirmuoju prioritetu, tačiau du penktadaliai neturi profesinio kryptingumo. Analizuojant, kurie studiju pasirinkimo veiksniai labiau lèmè studiju pasirinkima, nustatyta, kad kryptingai ir nekryptingai pasirinkusiems studiju programas svarbesni - vidiniai studiju pasirinkimo veiksniai. Vidinius ir išorinius studiju pasirinkimo veiksnius palankiau vertina respondentai, kryptingai pasirinkusieji studijas. Apibendrinant tyrimo metu gautus rezultatus galima daryti prielaida, kad didesné dalis respondentu profesija rinkosi kryptingai ir ju pasirinkimas atitiks tolesnius karjeros tikslus, uždavinius ir lūkesčius.

Tyrimo duomenys padès gerinti profesinio konsultavimo ir informavimo paslaugu kokybę.

Raktažodžiai: profesijos pasirinkimas, profesijos pasirinkimo veiksniai, profesinis kryptingumas.

\section{IVADAS}

$\mathrm{J}$ aunam žmogui labai svarbu tinkamai pasirinkti profesija, nes nuo to priklauso jo savigarba, vidinè asmens harmonija, savirealizacija, socialinè-ekonominè padètis, statusas visuomenèje, socialinis saugumas ir kt. B. H. Lemme (2003) akcentuoja, kad nuo pasirinktos profesijos pirmiausia priklauso socialinè-ekonominè padètis, kuri turi tris dedamąsias: ekonominę, socialinę ir darbinę, pastaroji vertinama pagal profesiją. R. Laužackas
(2005) teigia, kad plačiaja prasme profesijos rinkimasis sudetingas, nesibaigiantis, trunkantis visą gyvenimą procesas, turintis įvairių dedamujų ir sprendimų. Tinkamai pasirinkta profesija leidžia asmeniui patenkinti esminius poreikius, žmogus gali jaustis reikalingas ir vertinamas, turi galimybę tobulèti ir pan. M. Barkauskaitès (2007) nuomone, „profesine veikla žmogus patenkina pagarbos, draugystès, saugumo, savigarbos, pažinimo, savęs 
vertinimo jausmus“, atsiranda galimybė ugdytis teigiamas (laimès, pasitenkinimo, džiaugsmo, pasididžiavimo) ir neigiamas (streso, nusivylimo, depresijos, nerimo, nepasitikejjimo ir kt.) asmenybès savybes.“

Profesijos pasirinkimą lemia daugybė veiksnių. Daugelio autorių nuomone, tinkamas profesijos pasirinkimas priklauso nuo savęs pažinimo, įsitikinimų, vertybių ir nuostatų sistemos, pasirinktos profesijos ypatybiu žinojimo ir gebejjimo derinti šiuos svarbius kriterijus tarpusavyje (Kanopiené, Tureikytė, 2002; Valeckienè, 2005; Makūnas, Pugevičienė, 2005; Абасов, 2006; Выборнова, Дунаева, 2006; Šedžiuvienè, Urbonienè, 2008; Jovaiša, 2009. Mokslinès literatūros analizė leidžia teigti, kad profesijos pasirinkimą lemia vidiniai ir išoriniai veiksniai. Vidiniams veiksniams priskirtini asmens polinkiai, interesai, gabumai, savęs pažinimas, asmeninès savybès, vertybès, nuostatos ir kt., išoriniams - bendrasis pasirengimas, žinios apie pasirinktą profesiją, žinių, igūdžiu ir mokèjimu lygmuo, darbo rinkos tendencijos, šeimos ir artimuju itaka profesijos pasirinkimui ir kiti svarbūs asmenybès profesinio apsisprendimo veiksniai. Išoriniai veiksniai sugrupuoti i du blokus socialinius / ekonominius ir organizacinius / pedagoginius. Mokslininkai J. M. Roščina, M. A. Drūgovas (Рощина, Другов, 2002), A. Palujanskiené, R. Adomaitienè (2004), Z. Abasovas (Абасов, 2006), T. Lileikienè (2009) ir kt. akcentuoja, kad renkantis profesiją ypač svarbus veiksnys - asmens savikryptingumas, kuris siejamas su asmens gebejjimu suvokti savo galimybes ir gebejjimu jomis pasinaudoti. Savikryptingumas tiesiogiai susijęs su profesiniu kryptingumu. F. Balčiūnaite (2006) ir E. Rodzevičiūtė (2008), nagrinèdamos mokytojų profesinio kryptingumo ypatumus, teigia, kad profesinis kryptingumas leidžia asmeniui kūrybiškai dirbti, pasitiketi savimi, jausti pasitenkinimą savo veikla ir kt.

Pastaraisiais metais padidejo jaunų žmonių susidomejjimas sveikatos priežiūros ir socialinio darbo studiju programomis, ir tai liudija kasmet didejjantys stojančiuju konkursai. Kokie veiksniai turèjo itakos profesijos pasirinkimui, ar jauni žmonès turi profesini kryptinguma, kokios profesinio kryptingumo prielaidos, bandoma atsakyti šiame straipsnyje.

Nors îvairūs mokslininkai profesijos pasirinkimo ypatumus yra tyrinejęę, bet sveikatos priežiūros ir socialinio darbo programų studentu profesijos pasirinkimo tyrimu, vykdytu pastaruoju laiku, nebuvo. Tyrimo rezultatai leis dèstytojams kryptingai konsultuoti studentus planuojant karjerą ir tobulinti profesinio orientavimo paslaugu teikima.

Tyrimo tikslas - atskleisti sveikatos priežiūros ir socialinio darbo studijų programų studentų profesijos pasirinkimo ypatumus.

\section{TYRIMO METODIKA}

Tiriamieji. Buvo tiriami 317 sveikatos priežiūros ir socialinio darbo studiju programų I kurso studentai (268 moterys (85\%) ir 49 vyrai (15\%)). Visi respondentai suskirstyti i 5 amžiaus grupes. 1 grupè $(18-20 \mathrm{~m})-$.272 respondentai $(87 \%)$, $2(21-25$ m. $)-16(5 \%), 3(26-30$ m. $)-7$ (2\%), 4 (31-35 m.) - 8 (2,5\%), 5 (per 35 m.) 10 (3,5\%). Tyrimo rezultatai leidžia teigti, kad dauguma apklaustuju (87\%) profesiją renkasi iškart po vidurinès mokyklos baigimo.

Tyrimo organizavimas. Tyrimas atliktas 2009-2010 m. m. pradžioje, apklausiant sveikatos priežiūros ir socialinio darbo studiju programu I kurso studentus. Tiriamieji pasirinkti netikimybine atsitiktine atranka. Vykdant apklausą buvo laikomasi etikos principu: visi tiriamieji buvo informuoti apie tyrimo tikslą, duomenu anonimiškumą.

Tyrimo metodai: literatūros šaltinių analizè, apklausa raštu naudojant autorių sudarytą klausimyną. Sudarant klausimyną buvo vadovaujamasi logiškumo, nuoseklumo ir vienodumo principais. Tyrimo instrumentas sudarytas iš 3 prasminių klausimų blokų. Pirmą bloką sudaro sociodemografiniai klausimai (lytis, amžius, studijų programa ir kt.), antrą — klausimai, susiję su profesijos pasirinkimu (jie suskirstyti i 2 kategorijas - vidinius ir išorinius profesijos rinkimosi veiksnius), trečią — klausimai, susiję su profesiniu kryptingumu. Vertinant klausimyno teiginius tyrimo metu naudota 5 balų Likerto skalè, o apdorojant duomenis reikšmès verstos i absoliučius skaičius, kur visiškai sutinku - 5, sutinku - 4, iš dalies sutinku - 3, nesutinku - 2, visiškai nesutinku - 1. Vertinant apklausos duomenis buvo skaičiuotas įverčių balų vidurkis ir procentinis atsakymu i klausimus skirstinys. Norint patenkinti chi kvadrato $\left(x^{2}\right)$ testo sąlygas, buvo sumažintos kintamuju kategorijos taip: 5-4 atsakymai jungiami ir vertinami kaip teigiami, 3 - neutralūs, $1-2$ atsakymai jungiami ir vertinami kaip neigiami.

Atlikus bandomaji (žvalgomaji) tyrimą nustatyta, kad dviejų klausimyno teiginių Kronbacho alfa $<0,4$, todèl jie eliminuoti iš klausimyno. Gauti vidutinio skaliu Kronbacho alfa suderinamumo koeficientai: vidinių veiksnių $-0,675$, išorinių 0,625 . 
Statistinè analizè. Atliekant tyrimo duomenu statistinę analizę naudotas statistinis duomenu analizès paketas SPSS 13 ( Statistical Package for the Social Sciences) ir Windows Microsoft Office programine i̇ranga, skaičiuojant aprašomosios statistikos dydžius: dažnius, îverčių balų vidurkị (V), standartinį nuokrypi (SN). Kintamujų skirsnių normalumui nustatyti naudotas Kolmogorovo-Smirnovo testas, klausimyno vidinio suderinamumo analizė atlikta taikant Kronbacho alfa koeficienta, koreliacinè analizé — taikant Spirmeno koreliacijos koeficientą $\left(R_{s}\right)$.

Skirtumui tarp respondentu atsakymų vertinti naudotas chi kvadrato $\left(x^{2}\right)$ kriterijus. Statistiškai patikimas ryšys laikomas tada, kai $p$ reikšme lygi ar yra mažesnè už pasirinktą reikšmingumo lygmeni $(\alpha=0,05)$.

\section{REZULTATAI}

Respondentų buvo prašoma įvertinti studiju programų pasirinkimo veiksnius. 1 lentelèje pateikta vidinių ir studijų pasirinkimo veiksnių dažnių procentinis skirstinys, iverčiu balų vidurkiai ir standartiniai nuokrypiai. Labai svarbią vietą profesinejje pasirinkimo srityje turi asmenybès gabumai ir polinkiai profesijai. Tyrimo rezultatai atskleide, kad kiek daugiau nei septyni dešimtadaliai $(\mathrm{V}=$ 3,$94 ; \mathrm{SN}=0,87$ ) respondentų mano esą gabūs pasirinktai profesijai ir turi jai polinkių. Dauguma $(\mathrm{V}=3,85 ; \mathrm{SN}=0,93)$ respondentu kaip itin teigiamą vidinį veiksnị nurodè galimybę dirbti su žmonėmis. Pagalbą ir rūpinimąsi žmonėmis kiek daugiau nei pusè $(\mathrm{V}=3,62 ; \mathrm{SN}=1,02)$ respondentų taip pat vertina pozityviai, o trečdalis atsakiusiuju vertina neutraliai. Kaip teigiamą veiksni respondentai nurodè galimybę tobulèti — taip mano daugiau nei septyni dešimtadaliai apklaustuju $(\mathrm{V}=3,92 ; \mathrm{SN}=0,86)$. Šis veiksnys rodo, kad jauni žmonès pasirengę tobulèti profesinejje veikoje, siekti naujų žinių ir igūdžių.
Analizuojant koreliacini ryši tarp kintamujuc pastebimas statistiškai reikšmingas stiprus teigiamas koreliacinis ryšys tarp vidinių veiksnių teiginiu „Galimybè dirbti su žmonemis“ ir „Pasitenkinimą kelia rūpinimasis žmonėmis ir pagalbos suteikimas jiems". Spirmeno koreliacijos koeficientas, rodantis kryptingą respondentų studijų programos pasirinkima, yra vidutinio stiprumo $\left(\mathrm{R}_{\mathrm{s}}=0,699 ; \mathrm{p}=0,00\right)$, nes noras dirbti su žmonèmis teikiant pagalbą ir paslaugas itin svarbus sveikatos priežiūros ir socialinio darbo specialistams.

Respondentų išorinių organizacinių / pedagoginių studiju pasirinkimo veiksnių vertinimas pateiktas 2 lenteleje. Organizacinius / pedagoginius studiju pasirinkimo veiksnius apklaustieji sveikatos priežiūros ir socialinio darbo studijų programų I kurso studentai vertina gana pozityviai. Kaip teigia dauguma respondentu ( $\mathrm{V}=4,01 ; \mathrm{SN}=0,87)$, reikšmingiausi jiems iš šios grupès yra profesijos įdomumas, o daugiau nei dviem trečdaliams $(\mathrm{V}=3,86$; $\mathrm{SN}=0,91)$ apklaustujų svarbu užsigarantuoti ateiti. 3 lentelejje pateiktas socialinių / ekonominių veiksnių vertinimas, kuriuos respondentai vertina ne taip pozityviai, kaip organizaciniu / pedagoginiu studiju pasirinkimo veiksniu grupę. Daugiau nei trečdalis $(\mathrm{V}=3,05 ; \mathrm{SN}=1,19)$ respondentu teigia, $\mathrm{kad}$ rinktis studijas juos paskatino žinomo specialisto pavyzdys, o šeimos tradicijos turejo visai mažą itaką renkantis studijas, nes tik aštuoni nuošimčiai $(\mathrm{V}=1,90 ; \mathrm{SN}=0,98)$ apklaustujų teigia, kad jų pasirinkimą lèmé šeimos tradicijos. Daugiau nei trečdalis $(\mathrm{V}=3,09 ; \mathrm{SN}=1,03)$ respondentų nurodo, kad jiems labai svarbu ar svarbu profesijos pelningumas. Vertinant teigini „Geros issidarbinimo perspektyvos", daugiau nei trečdalis $(\mathrm{V}=3,27$; $\mathrm{SN}=0,86$ ) sutiko su teiginiu, bet daugiau nei puse laikosi neutralios pozicijos. Labai negatyvus teiginio „Norejjau igyti aukštojo mokslo diplomą, o profesija man nesvarbi“" respondentų vertinimas dauguma $(\mathrm{V}=1,59 ; \mathrm{SN}=0,86)$ apklaustujų visiškai negatyviai vertina teigini. Tyrimo rezultatai liudija,

\begin{tabular}{|c|c|c|c|c|c|c|}
\hline \multirow{4}{*}{$\begin{array}{l}1 \text { lentelè. Vidinių studi- } \\
\text { jų pasirinkimo veiksnių } \\
\text { vertinimas }\end{array}$} & \multirow[b]{2}{*}{ Teiginiai } & \multicolumn{3}{|c|}{ Vertinimas, $\%$} & \multirow[b]{2}{*}{$\mathbf{V}$} & \multirow[b]{2}{*}{ SN } \\
\hline & & Teigiamas & Neutralus & Neigiamas & & \\
\hline & $\begin{array}{l}\text { Jautète, kad esate gabus pasirinktai profesijai ir } \\
\text { turite jai polinkių }\end{array}$ & 70,3 & 25,5 & 4,2 & 3,94 & $\mathbf{0 , 8 7}$ \\
\hline & Galimybė tobulèti & 74,5 & 20,3 & 5,3 & 3,92 & 0,86 \\
\hline \multirow{3}{*}{$\begin{array}{l}\text { Pastaba. V-iverčių balų } \\
\text { vidurkis. SN - standarti- } \\
\text { nis nuokrypis. }\end{array}$} & $\begin{array}{l}\text { Pasitenkinimą kelia rūpinimasis žmonėmis ir } \\
\text { pagalbos suteikimas jiems }\end{array}$ & 55,8 & 33,4 & 10,7 & 3,62 & 1,02 \\
\hline & Galimybė dirbti su žmonèmis & 66,5 & 27,4 & 6,2 & 3,85 & 0,93 \\
\hline & Nepriklausomybė darbe & 32,1 & 28,9 & 39,0 & 2,99 & 1,13 \\
\hline
\end{tabular}




\begin{tabular}{|l|c|c|c|c|c|}
\hline \multicolumn{1}{|c|}{ Teiginiai } & \multicolumn{3}{c|}{ Vertinimas, \% } & \multirow{2}{*}{ V } & SN \\
\cline { 2 - 6 } & Teigiamas & Neutralus & Neigiamas & \\
\hline Turëjote praktinio darbo patirti & 10,9 & 10,9 & $\mathbf{7 8 , 1}$ & 1,98 & 1,08 \\
\hline Profesijos visuomeninè reikšmé & 29,3 & 40,6 & 30,0 & 2,99 & 1,07 \\
\hline Profesijos populiarumas & 30,6 & 39,1 & 30,3 & 3,06 & 1,00 \\
\hline Profesija atrodè ịdomi & 76,8 & 18,0 & 5,2 & $\mathbf{4 , 0 1}$ & $\mathbf{0 , 8 7}$ \\
\hline Noras užsigarantuoti ateiti & $\mathbf{6 5 , 1}$ & 27,4 & 7,5 & $\mathbf{3 , 8 6}$ & $\mathbf{0 , 9 1}$ \\
\hline
\end{tabular}

2 lentelè. Išorinių organizacinių / pedagoginių studijų pasirinkimo veiksnių vertinimas

\begin{tabular}{|l|l|l|l|l|l|}
\hline \multirow{2}{*}{ Teiginiai } & \multicolumn{3}{c|}{ Vertinimas, \% } & \multirow{2}{*}{ V } & \multicolumn{1}{|c|}{ SN } \\
\cline { 2 - 6 } & Teigiamas & Neutralus & Neigiamas & & \\
\hline $\begin{array}{l}\text { Paskatino žinomo (pažistamo) specialisto } \\
\text { pavyzdys }\end{array}$ & $\mathbf{3 6 , 0}$ & 27,2 & 36,9 & 3,05 & 1,19 \\
\hline Pasirinkta profesija pelninga & $\mathbf{3 3 , 2}$ & 39,4 & 33,2 & 3,09 & 1,03 \\
\hline Ši aukštoji mokykla yra netoli namų & 8,9 & 18,4 & $\mathbf{7 2 , 7}$ & 1,93 & 1,09 \\
\hline $\begin{array}{l}\text { Norėjau igyti aukštojo mokslo diplomą, o } \\
\text { profesija man nesvarbi }\end{array}$ & 3,7 & 7,6 & $\mathbf{8 1 , 7}$ & $\mathbf{1 , 5 9}$ & $\mathbf{0 , 8 6}$ \\
\hline Geros įdarbinimo perspektyvos & $\mathbf{3 3 , 8}$ & 51,8 & 14,4 & $\mathbf{3 , 2 7}$ & $\mathbf{0 , 8 6}$ \\
\hline Pasirinkimą lėmė šeimos tradicijos & 7,8 & 10,8 & $\mathbf{8 1 , 4}$ & 1,90 & 0,98 \\
\hline Patarè dirbantys pagal pasirinktą profesiją & 17,8 & 17,5 & 64,8 & 2,33 & 1,18 \\
\hline Trumpesnis studijų laikas nei universitete & 26,4 & 29,0 & 44,6 & 2,67 & 1,24 \\
\hline
\end{tabular}

3 lentelè. Išorinių socialinių / ekonominių studijų pasirinkimo veiksnių vertinimas

Pastaba. V - įverčiu balų vidurkis. $\mathrm{SN}$ - standartinis nuokrypis.

kad jauniems žmonėms, besirenkantiems studijas, itin svarbu profesijos pasirinkimas ir jos igijimas, o aukštojo išsilavinamo igijimas nèra lemiamas veiksnys.

Analizuojant koreliacini ryši tarp kintamųjų, pastebimas statistiškai reikšmingas vidutinis teigiamas koreliacinis ryšys tarp išorinių socialinių / ekonominių veiksnių teiginių ,Pasirinkta profesija pelninga“ ir ,Geros isidarbinimo perspektyvos“, Spirmeno koreliacijos koeficientas $\mathrm{R}_{\mathrm{s}}=0,443(\mathrm{p}=0,00)$. Galima daryti prielaida, kad uždarbis ir galimybe isidarbinti tarpusavyje koreliuoja teigiamai.

Nagrinėjant koreliacini ryši tarp vidiniu ir išorinių veiksnių kintamuju pastebimas statistiškai reikšmingas vidutinio stiprumo teigiamas koreliacinis ryšys tarp išorinių veiksnių teiginio „Profesija atrodè i̇domi“" ir vidinių veiksnių teiginio „Galimybè tobulèti“", Spirmeno koreliacijos koeficientas $\mathrm{R}_{\mathrm{s}}=0,503(\mathrm{p}=0,00)$.

Norint išsiaiškinti, kaip išoriniai ir vidiniai veiksniai lemia sveikatos priežiūros ir socialinio darbo studiju programų I kurso apklaustujų studentu profesini pasirinkima, buvo skaičiuoti vidutiniai teiginių balai. Sklaidos diagramoje regresinè tiesė rodo, kad tarp vidinių ir išorinių veiksnių yra teigiama tiesinė priklausomybè. Nors regresinès tiesès reikšmingumo koeficientas $\left(\mathrm{R}^{2}=0,203\right)$ nèra aukštas, Spirmeno koreliacijos koeficientas $\left(\mathrm{R}_{\mathrm{s}}=0,381 ; \mathrm{p}=0,00\right)$ patvirtina statistiškai patikimą silpną teigiamą ryši tarp kintamujų.

Aiškinantis respondentų profesini kryptingumą buvo klausiama, kurią specialybę savo prašyme jie ivardijo pirmuoju prioritetu. Du trečdaliai respondentų kryptingai rinkosi studijas, o keturi dešimtadaliai respondentų studijuoja ne tą studiju programą, kurią norèjo studijuoti (̌̌r. pav.). Rezultatai liudija, kad šie studentai neketino rinktis tos studijų programos, i kurią istojo. Galima daryti prielaida, kad keturi dešimtadaliai respondentų neturi profesinio kryptingumo. Nagrinejjant visos imties profesini kryptingumą nustatyta, kad skirtumas tarp atsakymų yra statistiškai reikšmingas $\left(x^{2}=6,97 ; p=0,01\right)$. Analizuojant profesinio pasirinkimo kryptingumą pagal studiju programas vienareikšmiškai galima teigti, kad dantų technologijos studiju programos apkaustieji I kurso studentai labai motyvuoti, jie visi itin kryptingai pasirinko šią studijų programą. Statistiškai reikšmingi skirtumai rasti burnos higie$\operatorname{nos}\left(x^{2}=9,80 ; p=0,00\right)$, kineziterapijos $\left(x^{2}=6,55\right.$; 
Pav. Kryptingai ir nekryptingai pasirinkusiųjų studijų programas pasirinkimo veiksnių įverčiai

Pastaba. * - statistiškai reikšmingas atsakymų rezultatu skirtumas $(\mathrm{p}<0,05)$; ** statistiškai reikšmingas atsakymų rezultatų skirtumas $(\mathrm{p}<0,01)$

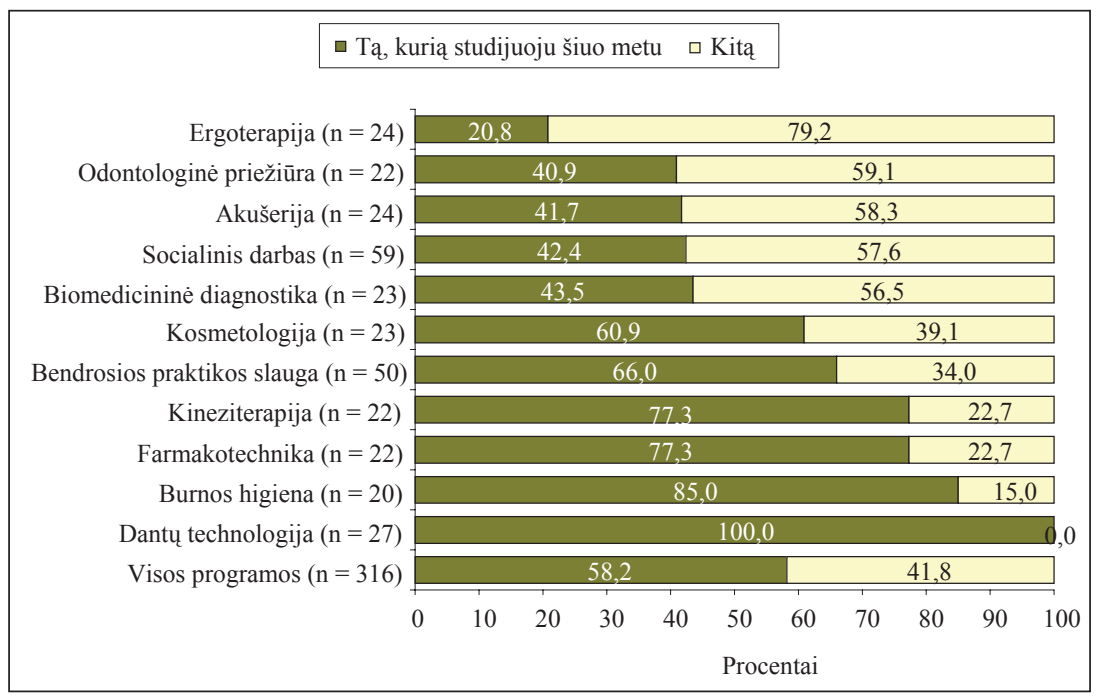

$\mathrm{p}=0,01)$ ir farmakotechnikos $\left(\mathrm{x}^{2}=9,8 ; \mathrm{p}=0,00\right)$ respondentų atsakymuose. Šių studiju programu dauguma respondentų studijas rinkosi pirmuoju prioritetu. Daugiau nei trys penktadaliai kosmetologijos $\left(x^{2}=1,09 ; p>0,05\right)$ ir bendrosios praktikos slaugos $\left(x^{2}=5,12 ; p=0,02\right)$ programu studentu, rinkdamiesi specialybę pirmuoju prioritetu, nurodè šiuo metu studijuojamą. Apie du penktadaliai keturiu studiju programu respondentu biomedicininès diagnostikos $\left(\mathrm{x}^{2}=0,39 ; \mathrm{p}>0,05\right)$, socialinio darbo $\left(\mathrm{x}^{2}=1,37 ; \mathrm{p}>0,05\right)$, akušerijos $\left(\mathrm{x}^{2}=0,39\right.$; $p>0,05)$, odontologinès priežiūros $\left(x^{2}=2,91\right.$; $\mathrm{p}=0,01)$ studijuojamas programas rinkosi pirmuoju prioritetu, bet respondentų atsakymai statistiškai nereikšmingi. Mažiausiai motyvuoti ir tvirto profesinio kryptingumo neturintys ergoterapijos $\left(\mathrm{x}^{2}=8,17\right.$; $\mathrm{p}=0,00)$ studiju programos respondentai, dauguma jų ergoterapijos studijas prašyme įvardijo ne pirmuoju prioritetu.

Atlikto tyrimo rezultatai rodo, kad kryptingai ir nekryptingai pasirinkusiems studiju programas svarbesni vidiniai studiju pasirinkimo veiksniai (palankiau juos vertina kryptingai pasirinkusieji studijas). Labiausiai motyvuoti dantų technologijos studiju programos apklaustieji I kurso studentai — visi studiju programą rinkosi pirmuoju prioritetu, mažiausią profesini kryptingumą turi ergoterapijos studiju programos respondentai, tik penktadalis respondentų studijų programą nurodè pirmuoju prioritetu.

\section{REZULTATŲ APTARIMAS}

Analizuojant sveikatos priežiūros ir socialinio darbo studijų programų I kurso studentų vidinius ir išorinius profesijos pasirinkimo veiksnius išryškèjo, kad vidiniai studijų pasirinkimo veiksniai yra stipresni už išorinius, bet abi veiksnių grupès yra glaudžiai susijusios ir stipriai veikia viena kitą. J. M. Roščinos, M. A. Drūgovo (Рощина, Другов, 2002), R. Kučinskienès (2003), R. Laužacko (2005), Z. A. Abasovo (Абасов, 2006), L. Jovaišos (2009) ir kt. mokslininkų nuomone, profesijos pasirinkimą lemia vidiniai ir išoriniai veiksniai.

Koreliacinè analizè parodè, kad tarp vidinių ir išoriniu veiksniu yra teigiama tiesinè priklausomybè. Dauguma respondentu pozityviai vertina savo gabumus ir polinkius pasirinktai profesijai, kurie priskiriami vidinių veiksniu grupei. Gerai pažinęs savo polinkius, interesus ir gabumus, asmuo gali tapti harmoninga asmenybe ir išvengti profesinių prieštaravimu — tai dažnai lemia studijų nutraukimą ar profesijos keitimą. Tyrimo rezultatai patvirtina J. Arnold (1997), V. Kanopienès, D. Tureikytès (2002), R. Laužacko (2005) ir kt. nuomonę, kad žmogui renkantis profesija jo polinkiai ir gebejimai suteikia tam tikrą profesini kryptingumą. Koreliacinè analizè rodo statistiškai reikšmingą vidutinio stiprumo teigiamą koreliacini ryši tarp vidinių veiksnių teiginiu „,Galimybè dirbti su žmonèmis“ ir „Pasitenkinimą kelia rūpinimasis žmonèmis ir pagalbos suteikimas jiems“. Vadinasi, respondentai neatsitiktinai rinkosi studijų programą ir profesiją, noras igyti sveikatos priežiūros ar socialinio darbo profesiją rodo jų profesini kryptingumą. Nagrinejjant koreliacinį ryši tarp vidinių ir išorinių veiksnių kintamujų, pastebimas statistiškai reikšmingas vidutinio stiprumo teigiamas koreliacinis ryšys tarp išorinių veiksniu teiginio „Profesija atrode i̇domi“ ir vidinių veiksnių teiginio „Galimybè tobulèti“. Pasak J. Arnold (1997), J. M. Roščinos, M. A. Drūgovo (Рощина, Другов, 2002), E. Rodzevičiūtès (2008), asmeniui nuolat tobulinantis, atnaujinant žinias, nepasiten- 
kinant tuo, ką pasiekè profesineje veikloje, jis kartu tobulina ir savo asmenybę, suteikia prasmę savo gyvenimui. Kadangi sveikatos priežiūros ir socialinio darbo paslaugos priskiriamos prie glaudžių kontaktų „žmogus - žmogui“" paslaugų, todèl itin svarbu, kad jauni specialistai turètų vidinę motyvaciją dirbti su žmonėmis ir nuolat tobulintu savo profesinę kvalifikacija, jautriai bei pozityviai reaguotų $i$ vykstančius pokyčius darbinès veiklos ir mokslo pasaulyje. Trečdalis respondentų rinkosi specialybę, laiduojančią gerą issidarbinamumą ir gerą atlygi. J. M. Roščinos, M. A. Drūgovo (Рощина, Другов, 2002), L. Jovaišos (2009) nuomone, labai svarbus profesinio rinkimosi išorinis veiksnys - darbo užmokestis, kuris kartais ir nulemia profesijos pasirinkimą.

Dauguma respondentų nepritare teiginiui „Norejau igyti aukštojo mokslo diplomą, o profesija man nesvarbi“. Tyrimo rezultatai prieštarauja E. Rodzevičiūtès (2008), tyrusios būsimų mokytojų stojimo iz universitetą motyvus. Jos tyrimu duomenimis, daugiau nei devyni dešimtadaliai respondentų nurodè reikšmingiausius stojimo i universitetą motyvus - aukštojo mokslo siekima. Apibendrinant tyrimo rezultatus galima teigti, kad sveikatos priežiūros ir socialinio darbo studijų programų I kurso studentams itin svarbu profesijos pasirinkimas ir jos igijimas, o aukštojo išsilavinamo igijimas nèra lemiamas veiksnys. Galima daryti prielaida, kad respondentai vidinius ir išorinius - organizacinius / pedagoginius profesijos pasirinkimo veiksnius vertina pozityviau nei socialinių / ekonominių veiksnių grupę.

Atlikto tyrimo rezultatai rodo, kad du trečdaliai respondentų studijas rinkosi kryptingai - pirmuoju prioritetu, bet du penktadaliai neturi profesinio kryptingumo. J. M. Roščinos, M. A. Drūgovo
(Рощина, Другов, 2002), R. Laužacko (2005), Z. Abasovo (Абасов, 2006) ir kt. nuomone, profesijos pasirinkimas dar neitvirtina asmens profesinių planų, tai tik vienas iš svarbių asmenybès profesinio tapsmo etapų. Jaunas žmogus gali pakeisti savo pasirinkimą, vien todèl, kad turèjo mažai informacijos apie profesiją.

Nagrinejant kryptingai studijas pasirinkusiu respondentų nuomonę nustatyta, kad išorinius studiju pasirinkimo veiksnius jie vertina pozityviau. Gauti tyrimo rezultatai liudija, kad abiem respondentų grupèms renkantis profesiją ịtakos turèjo vidiniai ir išoriniai veiksniai, bet vidiniai studiju rinkimosi veiksniai vertinami pozityviau.

Apibendrinant tyrimo rezultatus galima daryti prielaida, kad nemaža dalis respondentų profesiją rinkosi kryptingai ir jų pasirinkimas atitiks tolesnius karjeros tikslus, siekius ir lūkesčius.

\section{IŠVADOS}

Atlikto tyrimo rezultatai atskleidè, kad vidiniai studiju pasirinkimo veiksniai yra stipresni už išorinius, bet abi veiksnių grupès glaudžiai susijusios ir stipriai tarpusavyje sąveikauja, nes stiprèjant vienai veiksnių grupei stiprèja ir kita.

Du trečdaliai respondentu turi profesini kryptingumą, o keturi dešimtadaliai respondentų studijų programą rinkosi ne pirmuoju prioritetu, nes neturi profesinio kryptingumo. Vidinius ir išorinius studiju pasirinkimo veiksnius palankiau vertina kryptingai pasirinkusieji studijas. Tyrimo rezultatai leidžia daryti prielaida, kad kryptingo profesinio pasirinkimo asmenys yra giliau susipažinę su profesija, turi individualių gabumų ir polinkių, aiškių profesinių tikslų ir uždavinių, profesinis pasirinkimas atitiks tolesnius jų karjeros lūkesčius.

\section{LITERATŪRA}

Arnold, J. (1997). Nineteen propositions concerning the nature of effective thinking for career management in a turbulent word. British Journal of Guidance and Counselling 25 (4), $449-450$.

Balčiūnaitè, F. (2006). Būsimujų psichologijos mokytoju profesinio kryptingumo ypatumai. Pedagogika, 81, $24-28$.

Barkauskaite, M. (2007). Profesinio rengimo realijos. Profesinis konsultavimas ir orientavimas šiuolaikinio profesinio rengimo kontekste. Acta pedagogika Vilnensia, 18, $106-120$.

Jovaiša, L. (2009). Profesinio orientavimo ir konsultavimo psichologija. Vilnius: Agora.

Kanopiene, V., Tureikyte, D. (2002). Vilniaus universiteto studentų požiūris ì studijas. Filosofija, sociologija, 1, $68-76$.
Kardelis, K. (2002). Moksliniu tyrimu metodologija ir metodai. Kaunas: Judex.

Kučinskienė, R. (2003). Ugdymo karjerai metodologija: monografija. Klaipèda: KU.

Laužackas, R. (2005). Profesinio rengimo metodologija: monografija. Kaunas: VDU.

Lemme, B. H. (2003). Suaugusiojo raida. Kaunas: UAB Poligrafija ir informatika.

Lileikienè, T. (2009). Aukštesniujų klasių mokinių požiūris i karjeros sėkmingumą lemiančius veiksnius. Pedagogika, 93, 54-61.

Makūnas, V., Pugevičienė, D. (2005). Profesinio apsisprendimo veiksniu tyrimas Kauno kolegijos Kraštotvarkos fakultete. Mokslu taikomieji tyrimai Lietuvos kolegijose, 2, 35-41. 
Palujanskienè, A., Adomaitienè, R. (2004). Profesinè paauglių ir jaunuoliu raida. Pedagogika, 74, 129-136.

Rodzevičiūtè, E. (2008). Pedagogo profesijos pasirinkimo motyvacija ir jos kaita pedagoginiu studiju metu. Profesinis rengimas: tyrimai ir realijos, $15,74-85$.

Šedžiuvienè, N., Urbonienè, L. (2008). Profesinis orientavimas aukštojoje mokykloje: veiklos principai ir kryptys. Pedagogika, 90, 18-25.

Valeckienè, D. (2005). Profesijos pasirinkimą lemiančiu veiksnių teorinè analizé [žiūrèta 200912 03]. Prieiga internetu: http://www.smk.lt/galery/_klsmk/mokslas/karjera/ dziuginta_valeckiene.pdf
Абасов, 3. А. (2006). Проектирование студентами педвуза профессиональной стратегиию [žiūrèta 2010 0503 ]. Prieiga internetu: http://www.isras.ru/files/File/ Socis/1-6-2006/abasov.pdf>.

Выборнова, В. В., Дунаева Е. А. (2006). Актуализация проблем профессионального самоопределения молодёжи [žiūrèta 201010 31]. Prieiga internetu: http://www. ecsocman.edu.ru/data/675/876/1219/010_vybornova.pdf

Рощина, Я. М., Другов, М. А. (2002). Выбор профессии: по любви или по расчёту? Москва.

\title{
PECULIARITIES OF STUDENTS' CHOICE OF PROFESSION IN HEALTH CARE AND SOCIAL WORK PROGRAMS
}

\author{
Ramutẻ Rimkienė, Danguolè Grūnovienė, Albina Vaičiulevičienė \\ Kaunas College, Kaunas, Lithuania
}

\begin{abstract}
The choice of profession is one of the most important steps in a person's life. Person's psychological social and economic conditions depends on the proper choice of profession. The person feels important when he does what he loves, tries to improve their knowledge and skills and feels satisfaction doing it. The choice of profession is a complicated, multi-purposeful and never ending process, which is influenced by internal and external factors. The article analyzes a variety of determinant factors and their importance in choosing the studies in health care and social work programs. It aims to find out which factors are more important to students' direct and indirect choices of studies.

Research objective was to discover the peculiarities that determine health care and social work students' choices of profession.

Research assume that the choise of a profession is governed by internal and external factors. Person's predisposition, interests, aptitude, self-knowledge, individual characteristics, values, attitude and other features belong to internal factors. General preparation, knowledge about the chosen profession, skills and competence level, work force tendencies, family and relatives' influence and other factors are external factors which are important to individual's decision in choosing a profession.

The results of our research showed that internal factors in the choice of studies were insignificantly stronger than external factors, but both factor groups were closely related and influenced one another. Correlation analysis demonstrated that with the increase of one factor group the other group increases as well. Spearman's correlation coefficient was $\mathrm{R} 2=0.381, \mathrm{p}=0.00$ and indicate statistically reliable and weak positive connection between variables. The results of research presented that two thirds of the respondents chose studies directly as their first priority, but two fifths of the respondents did not have professional purposefulness. While analyzing which factors the selection of studies influenced the choice more, we discovered that more important were the internal choice factors in direct and indirect choice of study programs. The respondents, who chose the studies as their top choice valued internal and external choice factors more favourably. In summary, the results of the research suggest that a bigger part of respondents chose the profession directly and their choice would match their future career goals, tasks and expectations.
\end{abstract}

The results of the research will help to ensure professional consulting and advising service quality.

Keywords: choice of profession, factor of professional choice, professional purposefulness. 